\title{
TREATMENT OF DAIRY WASTE BY ANAEROBIC CO-DIGESTION WITH SEWAGE SLUDGE
}

\author{
OBRÓBKA ODPADÓW MLECZARSKICH Z ZASTOSOWANIEM \\ KOFERMENATCJI Z OSADEM ŚCIEKOWYM
}

\begin{abstract}
The results of anaerobic digestion (AD) of buttermilk (BM) and cheese whey (CW) with a digested sewage sludge as inoculum is described. The substrate/inoculum mixtures were prepared using $10 \%$ buttermilk and $15 \%$ cheese whey. The essential parameters of the materials were described, including: total solids (TS), volatile solids (VS), $\mathrm{pH}$, conductivity, $\mathrm{C} / \mathrm{N}$ ratio (the quantitative ratio of organic carbon (C) to nitrogen $(\mathrm{N})$ ), alkalinity, chemical oxygen demand (COD). The potential directions of biodegradation of the organic waste types, as used in this study, are also presented. Appropriate chemical reactions illustrate the substrates and products in each phase of anaerobic decomposition of the compounds that are present in buttermilk and cheese whey: lactic acid, lactose, fat, and casein. Moreover, the biogas and biomethane production rates are compared for the substrates used in the experiment. The results have shown that buttermilk in AD generates more biogas (743 $\left.\mathrm{m}^{3} / \mathrm{Mg} \mathrm{VS}\right)$, including methane $\left(527 \mathrm{~m}^{3} / \mathrm{Mg} \mathrm{VS}\right)$, when compared with cheese whey $\left(600 \mathrm{~m}^{3} / \mathrm{Mg} \mathrm{VS}\right.$, $338 \mathrm{~m}^{3} / \mathrm{Mg}$ VS for biogas and methane, respectively).
\end{abstract}

Keywords: anaerobic digestion, cheese whey, buttermilk, digested sewage sludge, biodegradation, biomethane efficiency

\section{Introduction}

Dynamic urbanization and fast development of human population contribute to the generation of a high volume of sewage sludge, one of the main byproducts in waste

\footnotetext{
${ }^{1}$ Institute of Food Technology of Plant Origin, Poznan University of Life Sciences, ul. Wojska Polskiego 28, 60-637 Poznań, Poland, phone +48 6184873 08, email: pilarska@up.poznan.pl

${ }^{2}$ Institute of Biosystems Engineering, Poznan University of Life Sciences, ul. Wojska Polskiego 28, 60-637 Poznań, Poland, email: pilarski@up.poznan.pl; witaszek@up.poznan.pl

${ }^{3}$ Institute of Chemical Wood Technology, Poznan University of Life Sciences, ul. Wojska Polskiego 28, 60-637 Poznań, Poland, email: mzbor@up.poznan.pl; bwaliszewska@up.poznan.pl; waliszewska.hanna@gmail.com

${ }^{4}$ Department of Research and Development, Aquanet S.A., Dolna Wilda 126, 61-492 Poznań, Poland, email: marek.kolasinski@aquanet.pl

${ }^{5}$ Centre of Advanced Technologies, Adam Mickiewicz University, ul. Umultowska 89C, 61-614 Poznań, Poland, email: karolinaszwarc-rzepka@wp.pl

* Corresponding author: pilarska@up.poznan.pl
} 
treatment. Many sludge treatment and disposal processes are used at present, for instance: composting, landfill, land application as well as incineration. Compared with the above-mentioned methods, anaerobic digestion is the cheapest and most effective method, in addition to being environmentally-friendly [1]. At present, it is the most widely used method for mineralization of the organic content of sludge in biological waste treatment plants. Digestion helps produce humified sludge with high fertilizer qualities, which is free of pathogens, and does not generate any unpleasant smell during storage [2]. The digested sewage sludge also has a lower content of volatile fatty acids (VFA) and higher alkalinity: this means higher buffer capacity, which is especially important during its use as inoculum. Unfortunately, owing to the limited content of solids sewage sludge as well as the presence of inhibiting compounds, such as heavy metals [3], biogas production in anaerobic digestion (AD) with the use of raw sewage sludge (raw SS) is very low. Combining a raw sewage sludge as a co-substrate with assorted kinds of waste, such as food-processing [4], agricultural [5, 6], municipal waste [7] in anaerobic co-digestion (AcoD) is a well known and widely accepted method in some countries, for instance, in Germany and Scandinavia [8] - the pioneering countries developing their biogas production experiments for the last two decades.

Our literature survey indicates that there exist technological reasons for the choice of waste types and ratios [9] that are suitable for preparing a digestion mixture for AcoD. Its composition, as shown in previous studies, is decisive for: the biogas yield, reactor stability, and solids destruction efficiency. The most direct benefits of a suitable choice of substrates include $\mathrm{pH}$ control, improved balance of nutrients, and reduced action of inhibitory compounds. The raw and digested sewage sludge is characterized by high buffer capacities which enable optimum $\mathrm{pH}$ ranges from 6.8 to 7.5 for the $\mathrm{AD}$ [10]. Literature data indicate that an addition of sewage sludge in AcoD may be beneficial both in the case of fruit and vegetable waste and glycerin or fat [11].

The substrates used in the present work were cheese whey (CW) and buttermilk (BM) waste, combined with a digested sewage sludge. Cheese whey is a byproduct of cheese making. It has a high content of hydrocarbons, including - mainly - lactose, soluble proteins as well as lipids, mineral salts comprising $\mathrm{NaCl}, \mathrm{KCl}$, calcium salts. Cheese whey is also rich in lactic acid, citric acid, and B group vitamins [12]. Its exceptionally high content of organic substances is rather problematic in the aspect of its treatment as waste. In a method of its disposal, cheese whey is subjected to anaerobic digestion, although AD is not very popular in the dairy industry, mainly because of problems with its realization. Having a high lactose content, cheese whey tends to have an acidification effect early during $\mathrm{AD}$, resulting in reduced levels of $\mathrm{pH}$. The yield of $\mathrm{AD}$ of cheese whey is low, which is connected also with low $\mathrm{pH}$ of cheese whey $[13,14]$. Another cause is the high content of $\mathrm{Na}^{+}$in a salty whey [15], inhibiting the AD process. Previous studies on the disposal of CW by anaerobic digestion were focused on various methods to improve the process efficiency and stability. The most important methods include: (i) longer hydraulic retention time (HRT) [16], (ii) use of different process configurations [17], and (iii) suitable choice of co-substrates. It is a frequent practice to combine methods. The substrates that have been used in studies before, such as: vegetable and fruit waste [18], cow manure [19], dairy manure [14, 17], cattle slurry [20], ensiled sorghum and cow manure [16], do not only function as buffers: they also provide a better nutrient balance, ultimately contributing to higher biomethane or biohydrogen production rates. There is no report on any AD process with the use of cheese whey with digested or raw sewage sludge. 
Buttermilk is the aqueous phase left behind after churning butter out of cream. Its chemical composition tends to vary with that of the milk. On average, it is $91 \%$ water plus 9\% dry matter, including: lactose, nitrogen compounds, fat, and other mineral compounds [21]. Buttermilk - just as cheese whey - is characterized by high concentrations of soluble organic matter and is readily biodegradable; this makes this residue particularly suitable for anaerobic digestion. Buttermilk waste, as a product of the dairy industry, can be utilized as a substrate for biogas plants, in co-fermentation with other waste types, such as cattle slurry [22]. In contrast to cheese whey, no reports have been found in literature describing studies dedicated to digestion of buttermilk as a sole material.

It was the objective of this paper to analyze and compare biogas and biomethane yields of dairy waste using the example of buttermilk and cheese whey. The inoculum was a digested sewage sludge. The studies reported in this paper were carried out in a laboratory scale in anaerobic batch reactors, in controlled (mesophilic) ranges of temperature and $\mathrm{pH}$. In comparison with the information reported in literature, the authors of presented article, obtained the same results for buttermilk and somewhat better ones for cheese whey.

\section{Materials and methods}

Substrates and inoculum. The digested sewage sludge (inoculum) samples were obtained from a biogas plant (2.793 MW) operating at the municipal wastewater treatment plant in Aquanet S.A, Poznan. Buttermilk waste and cheese whey were provided by a dairy company located about $50 \mathrm{~km}$ from Poznan. The characteristics of the substrates used in this study are shown in Table 1.

Biogas production set-up and procedure. The digestion mixture ratios were established according to the VDI 4630 guideline concerning digestion of organic materials, substrate characterization, sampling, collection of material data, and digestion tests [23]. Based on the said guideline, the authors attempted to keep the solids content (total solids, TS) of the batch at $10 \%$ of less to guarantee adequate mass transfers, the C:N ratio of the mixtures was in the range 10-30, and the $\mathrm{pH}$ of the mixture before digestion was between 6.8 and 7.5. The mixture compositions and some of their parameters are shown in Table 2.

Biogas production rates as well as biogas and methane yield analyses were carried out in accordance with the German standard DIN 38 414-S8 [24]. The methane digestion process was carried out in a multichamber biofermenter (Fig. 1).

The authors used 9 digestion chambers in these tests; each substrate and the control were digested in 3 repetitions. Five $1.4-\mathrm{dm}^{3}$ biofermenters were filled each with $1 \mathrm{dm}^{3}$ of a starting material comprising suitable substrate mixtures. The material was stirred once daily (every $24 \mathrm{hrs}$ ). In the absence of oxygen in the digestion chamber, the inoculum was added, creating the perfect conditions for methane production. The biofermenters were provided with a water jacket (3) connected to a heater (1) in order to control the temperature and perform the process in a desirable temperature range. The study was carried out in mesophilic temperature conditions (at $c a 39^{\circ} \mathrm{C}$ ). The biogas produced was transported, via tube (6), into tanks (7) after filling them with a neutral liquid. In accordance with the VDI 4630 guideline, the experiment was continued for a given substrate until the daily biogas production was lower than $1 \%$ of the total generated amount of biogas [23]. Retention times for the materials used in this study (cheese whey and buttermilk) were similar and relatively short (Fig. 2). 


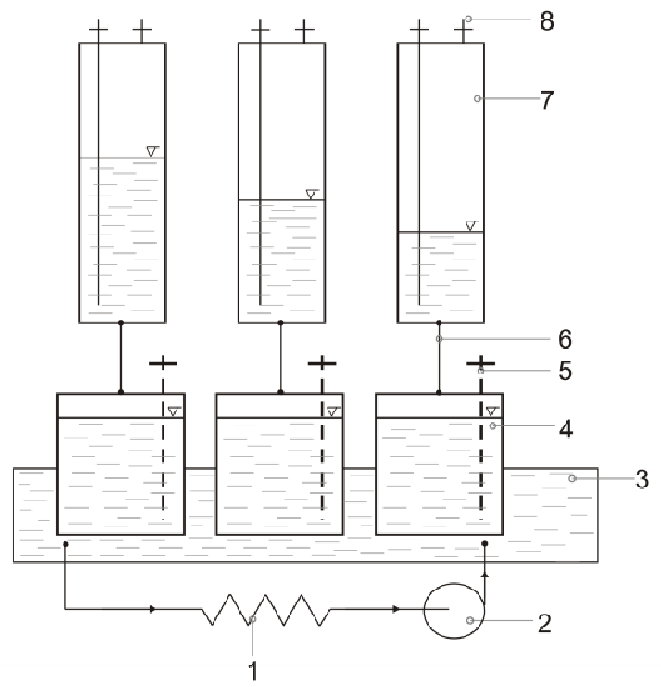

Fig. 1. Biofermenter for biogas production tests (6-chamber section): 1 - water heater with temperature adjustment, 2 - water pump, 3 - water jacket $\left(39^{\circ} \mathrm{C}\right), 4$ - biofermenter $\left(1.4 \mathrm{dm}^{3}\right), 5$ - slurry-sample drawing tube, 6 - tube for transporting the biogas formed, 7 - graduated tank for biogas, 8 - gas sampling valve

\section{Analytical methods}

Analysis of substrates. The substrates and inoculum were analyzed according to Polish standards or procedures: dry mass/humidity (drier method PN-75 C-04616/01), organic matter and ash (incineration according to the modified PN-Z-15011-3), pH (potentiometric method PN-90/A-75101.06), conductivity (PN-EN 27888:1999) [25]. Total nitrogen - Kjeldahl method, total organic carbon (Tiurin's method), total-P (spectrophotometric method), alkalinity (potentiometric titration method), as well as COD (titration method), were also determined according to relevant standards, ie: PN-EN ISO 5667-13:2011, PN-EN ISO/IEC 17025:2005, PN-EN ISO 9963-1:2001 [26-28].

Analysis of gas samples. The gas volumes generated were measured once daily. Qualitative analyses of the gas were carried out for the gas volumes of not less than $1 \mathrm{dm}^{3}$, initially once a day, then - as lower volumes were generated - once in three days.

The levels of methane, carbon dioxide, hydrogen sulfide, ammonia, and oxygen were measured using IR absorption sensors and an electrochemical sensor line. Measurements of the gas concentration were performed using Mg-72 and Mg-73 measurement devices from Alter S.A. The gas monitoring system was calibrated once a week using calibrating mixtures from Air Products, which were used at the following concentrations: $65 \% \mathrm{CH}_{4}$,

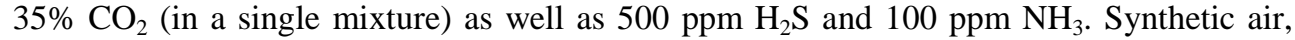
having an $\mathrm{O}_{2}$ content of $20 \%$, was used for calibration of $\mathrm{O}_{2}$.

Calculation of cumulative biogas and methane. After completing the quantitative and qualitative analyses of the gas obtained, the last step is to assess the biogas yield per unit of organic dry matter in the reactors filled with the substrate mixtures or the reference substrates, the ratio of gas generated from the seeding sludge in the test is calculated from the equation below: 


$$
V_{I S(\text { corr. })}=\frac{\sum V_{I S} m_{I S}}{m_{M}}
$$

where: $V_{I S(\text { corr. })}$ - gas volume, released from the seeding sludge $\left[\mathrm{ml}_{\mathrm{N}}\right]$ (milliliter normal); $\Sigma V_{I S}$ - the total gas volumes in the test performed on seeding sludge for the given test duration $\left[\mathrm{ml}_{\mathrm{N}}\right] ; m_{I S}$ - mass of the seeding sludge used for the mixture [g]; and $m_{M}$ - mass of the seeding sludge used in the control test $[\mathrm{g}]$.

The specific digestion gas production $V_{S}$ from the substrate or reference substrate vs. test duration, is calculated step by step from reading to reading in accordance with the equation:

$$
V_{S}=\frac{\sum V_{n} 10^{4}}{m w_{T} w_{V}}
$$

where: $V_{S}$ - specific digestion gas production relative to the ignition loss mass during the test period $\left[1_{N} / \mathrm{kgGV}\right]\left(\mathrm{GV}\right.$ - loss on ignition); $\Sigma V_{N}$ - net gas volume of the substrate or reference substrate for the given test time $\left[\mathrm{ml}_{\mathrm{N}}\right] ; m$ - mass of the weighed-in substrate or reference substrate $[\mathrm{g}] ; w_{T}$ - dry residue of the sample or of the reference sludge [\%]; and $w_{V}$ - loss on ignition of dry mass of the sample or of the reference sludge [\%].

\section{Results and discussion}

Substrates and inoculum characterization. Buttermilk waste (BM) and cheese whey (CW), as used in the present work, are characterized by the total solids (TS) content of 7.44 and $4.43 \%$ and volatile solids contents of: 92.58 and $84.21 \%$, respectively, as shown in Table 1. Higher values of TS and VS for buttermilk led to higher production rates of biogas (including methane) in the $\mathrm{AD}$ process that was carried out using the material. Both $\mathrm{BM}$ and $\mathrm{CW}$ have similar, rather low $\mathrm{pH}$ values: 4.32 for $\mathrm{BM}$ and 4.45 for $\mathrm{CW}$. Their low acidic $\mathrm{pH}$ values result, first of all, from the presence of lactic acid. Moreover, higher conductivity $(23.20 \mathrm{mS} / \mathrm{cm})$ was recorded for cheese whey; this confirms the presence in the material of alkali earth metal ions, including $\mathrm{Na}^{+}, \mathrm{K}^{+}, \mathrm{Ca}^{2+} . \mathrm{C} / \mathrm{N}$ ratios for $\mathrm{BM}$ and $\mathrm{CW}$ of 33 and 38, respectively, are sufficient to enable the development of methanogenic bacteria. The above parameters of the materials are comparable to literature data [21].

Table 1

Characteristics of the buttermilk (BM), cheese whey $(\mathrm{CW})$ and inoculum used for the studies

\begin{tabular}{|c|c|c|c|c|}
\hline Indicator & Unit & BM & CW & Inoculum \\
\hline $\mathrm{TS}$ & {$[\%]$} & 7.44 & 4.43 & 3.46 \\
\hline $\mathrm{VS}$ & {$[\% \mathrm{TS}]$} & 92.58 & 84.21 & 71.53 \\
\hline $\mathrm{pH}$ & - & 4.32 & 4.45 & 7.95 \\
\hline Conductivity & {$[\mathrm{mS} / \mathrm{cm}]$} & 16.40 & 23.20 & 26.60 \\
\hline $\mathrm{C} / \mathrm{N} \mathrm{ratio}$ & - & 33 & 38 & 11 \\
\hline $\mathrm{C}$ & {$[\% \mathrm{TS}]$} & 40.74 & 36.21 & 2.06 \\
\hline $\mathrm{N}$ & {$[\% \mathrm{TS}]$} & 1.25 & 0.95 & 2.48 \\
\hline${\mathrm{N}-\mathrm{NH}_{4}{ }^{+}}^{\mathrm{P}_{\text {total }}}$ & {$[\% \mathrm{TS}]$} & 0.35 & 0.32 & 2.66 \\
\hline Alkalinity & {$[\% \mathrm{TS}]$} & 0.09 & 0.12 & 4150 \\
\hline $\mathrm{COD}$ & {$\left[\mathrm{mg} \mathrm{CaCO}_{3} / \mathrm{dm}^{3}\right]$} & 273 & 352 & 1750 \\
\hline
\end{tabular}


The concentration of ammonium nitrogen $\mathrm{N}^{-\mathrm{NH}_{4}}{ }^{+}$which is known to have an inhibitory effect on anaerobic digestion for $\mathrm{BM}(0.35 \%), \mathrm{CW}(0.32 \%)$, as well as for a digested sludge - or the inoculum $(2.48 \%)$ - does not exceed the critical ammonia $N$ concentration [29]. Buttermilk (273 $\left.\mathrm{mg} \quad \mathrm{CaCO}_{3} / \mathrm{dm}^{3}\right)$ and cheese whey (352 $\mathrm{mg} \mathrm{CaCO} / \mathrm{dm}^{3}$ ) in the present study had alkalinities similar to those reported in literature [16]. The high content of organic substances in both kinds of waste determines their high Chemical Oxygen Demand (COD) $[13,21]$ which, according to the findings, is $103560 \mathrm{mg} / \mathrm{dm}^{3}$ for buttermilk and $65700 \mathrm{mg} / \mathrm{dm}^{3}$ for cheese whey.

Digested sewage sludge (inoculum) has a low content of TS $(3.46 \%)$ and a nearly neutral $\mathrm{pH}$ (Table 1). Besides, it is characterized by rather high conductivity $(26.6 \mathrm{mS} / \mathrm{cm}$ ), indicating the presence of mineral components which may favor the growth and metabolism of anaerobic bacteria and, therefore, also methane production rate. According to the results, the inoculum has higher concentrations of potassium, magnesium, and calcium, compared with the raw SS (sewage sludge). Moreover, the inoculum characterized by relatively high alkalinity $\left(4150 \mathrm{mg} / \mathrm{dm}^{3}\right)$, which can be essential for maintaining a stable course of the AD process for the dairy waste used.

Buttermilk and cheese whey biodegradation. The buttermilk and cheese whey decomposed in this experiment have very similar chemical compositions. Their main biodegradable components are: lactic acid, lactose (so-called "lactic sugar"), fat, and casein. Based on the date in literature [30], as well as chemical knowledge and experience [31-33], the authors of presented paper, have proposed the possible directions of biodegradation for the organic waste materials in this experiment; they are shown in the form of chemical reactions (1) to (47). Knowledge about intermediate products of biodegradation of organic matter used as the feed in biogas plants is very important for maximization of the efficiency of anaerobic digestion. This provides information, not only on the potential methane production, which results from stoichiometry, but also on the duration of digestion of the respective materials by the bacteria, and inhibitors which are generated in the biodegradation process.

Hydrolysis

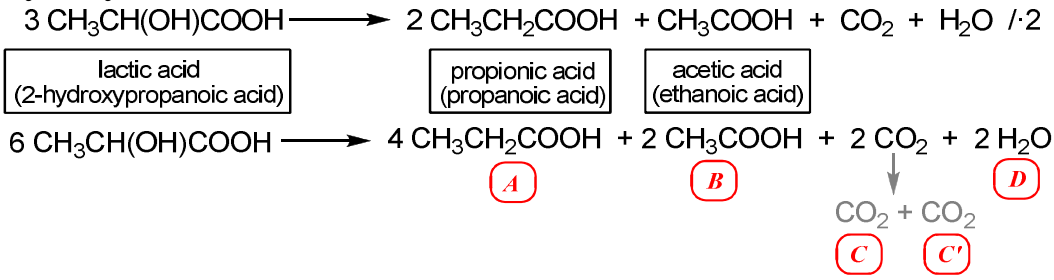

Acidogenic phase

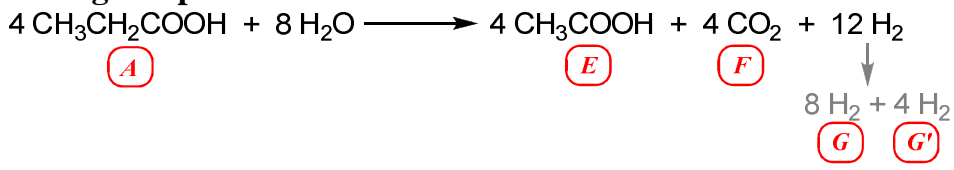




\section{Acetogenic phase}

$$
4 \mathrm{CO}_{2}+8 \mathrm{H}_{2} \longrightarrow 2 \mathrm{CH}_{3} \mathrm{COOH}+4 \mathrm{H}_{2} \mathrm{O}
$$

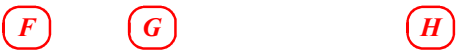

\section{Methanogenic phase}

$$
\begin{aligned}
& 2 \mathrm{CH}_{3} \mathrm{COOH}+4 \mathrm{CH}_{3} \mathrm{COOH}+2 \mathrm{CH}_{3} \mathrm{COOH} \longrightarrow 8 \mathrm{CH}_{4}+8 \mathrm{CO}_{2} \\
& \mathrm{CO}_{2}+4 \mathrm{H}_{2} \longrightarrow \mathrm{CH}_{4}+2 \mathrm{H}_{2} \mathrm{O}
\end{aligned}
$$

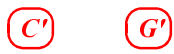

Biodegradation of lactic acid may initially (in hydrolysis) lead to the formation of propionic acid, acetic acid, carbon dioxide, and water (1). Propionic acid, in the acidogenic phase, is decomposed into $\mathrm{CH}_{3} \mathrm{COOH}, \mathrm{CO}_{2}$ and $\mathrm{H}_{2}$ (3). The second product, acetic acid, can be digested by methanogens and converted into $\mathrm{CH}_{4}$ and $\mathrm{CO}_{2}(5)$. Hydrogen $(\mathrm{G})$ and carbon dioxide (F) are, respectively, reactants for the synthesis of molecules of acetic acid $(\mathrm{H})$ and water in the acetogenic phase (reaction (3)). In the methanogenesis phase, acetic acid from the respective phases $(\mathrm{B}, \mathrm{E}, \mathrm{H})$ is biodegraded into $\mathrm{CH}_{4}$ and $\mathrm{CO}_{2}(5)$. At this stage, $\mathrm{CO}_{2}$ and $\mathrm{H}_{2}$ - the products of hydrolysis and acidogenic phase - enable microorganisms to generate more methane and water (6).

\section{Hydrolysis}

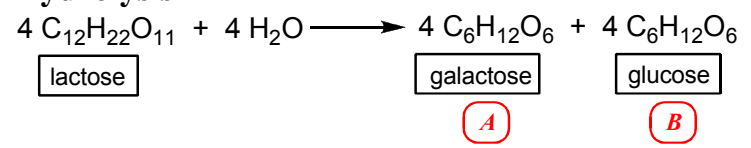

\section{Acidogenic phase}



\section{Acetogenic phase}

$$
\begin{aligned}
& \mathrm{C}_{2} \mathrm{H}_{5} \mathrm{OH}+\mathrm{H}_{2} \mathrm{O} \longrightarrow \mathrm{CH}_{3} \mathrm{COOH}+2 \mathrm{H}_{2} \\
& 4 \mathrm{C}_{6} \mathrm{H}_{12} \mathrm{O}_{6}+8 \mathrm{H}_{2} \mathrm{O} \longrightarrow 8 \mathrm{CH}_{3} \mathrm{COOH}+8 \mathrm{CO}_{2}+8 \mathrm{H}_{2}+4 \mathrm{H}_{2}+4 \mathrm{H}_{2} \\
& \text { (A) } \operatorname{or} \\
& \text { (I) } \\
& \text { (R) } \mathrm{K}
\end{aligned}
$$




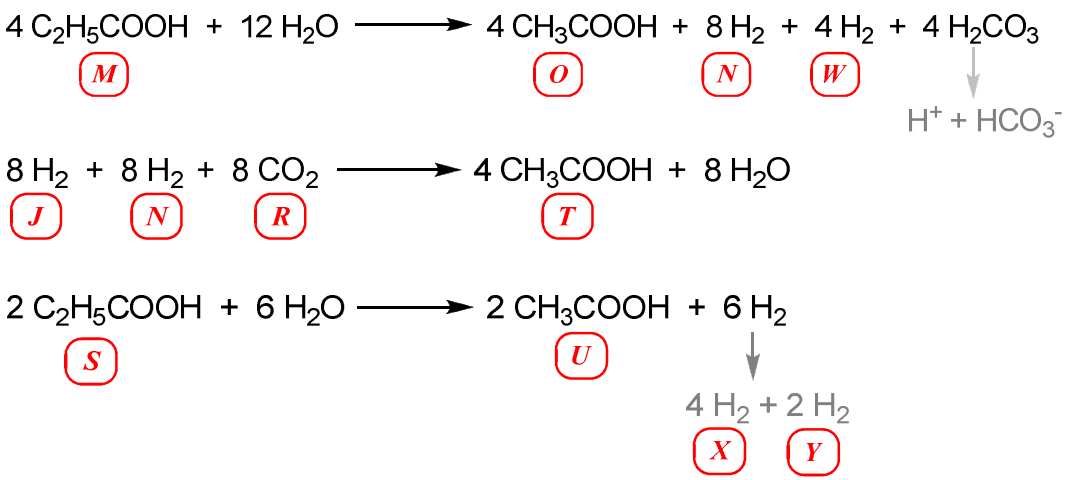

Methanogenic phase

$2 \mathrm{C}_{2} \mathrm{H}_{5} \mathrm{OH}+\mathrm{CO}_{2} \longrightarrow \mathrm{CH}_{4}+2 \mathrm{CH}_{3} \mathrm{COOH}+\mathrm{H}_{2}$

(s)

$\mathrm{CH}_{3} \mathrm{COOH}+8 \mathrm{CH}_{3} \mathrm{COOH}+8 \mathrm{CH}_{3} \mathrm{COOH}+2 \mathrm{CH}_{3} \mathrm{COOH} \longrightarrow 19 \mathrm{CH}_{4}+19 \mathrm{CO}_{2}$

$2 \mathrm{CO}_{2}+2 \mathrm{H}_{2}+4 \mathrm{H}_{2}+2 \mathrm{H}_{2} \longrightarrow 2 \mathrm{CH}_{4}+4 \mathrm{H}_{2} \mathrm{O}$

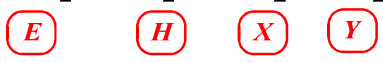

The hydrolysis of lactose, as another component of buttermilk and cheese whey, produces galactose and glucose (7) [34]. In the next stage, the products (A and B) are decomposed into ethanol and carbon dioxide (8) and/or propionic acid and water (9). In the acetogenic phase, alcohol reacts with water, producing acetic acid (10). In that stage, acetic acid (in addition to $\mathrm{CO}_{2}$ and $\mathrm{H}_{2}$ ) may be produced also by decomposition of galactose or glucose, which have not been completely digested by the hydrolytic bacteria (11). At this stage, the authors envisage also other directions of the formation of acetic acid: from propionic acid $(12,14)$ as well as from $\mathrm{H}_{2}$ and $\mathrm{CO}_{2}(13)$. In the methanogenic phase of decomposition of lactose, ethanol potentially combines with $\mathrm{CO}_{2}$, resulting in the formation of $\mathrm{CH}_{4}$ and propionic acid (15) as final products. Other possible directions of the formation of $\mathrm{CH}_{4}$ involve decomposition of the acetic acid molecules that were formed in the preceding stage (16) and bonding between $\mathrm{CO}_{2}$ and $\mathrm{H}_{2}$ in such amounts as are indicated by stoichiometry (17).

\section{Hydrolysis}

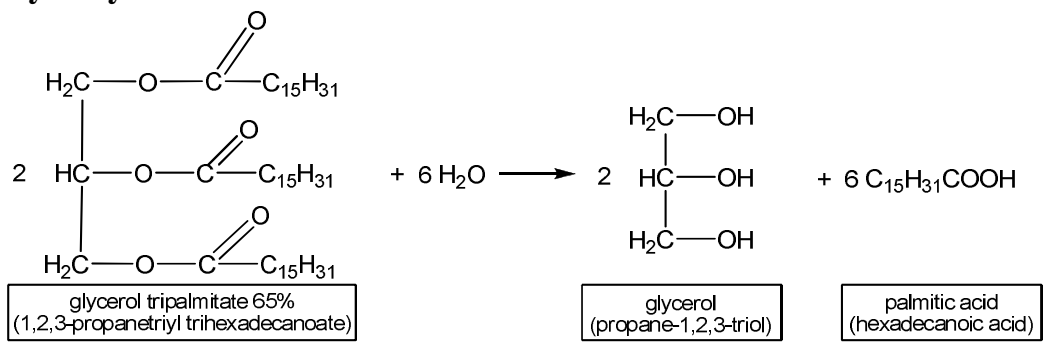




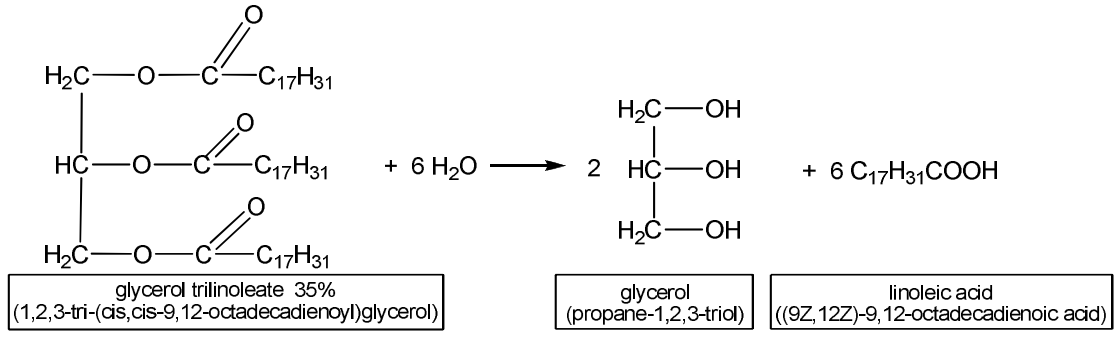

\section{Acidogenic phase}

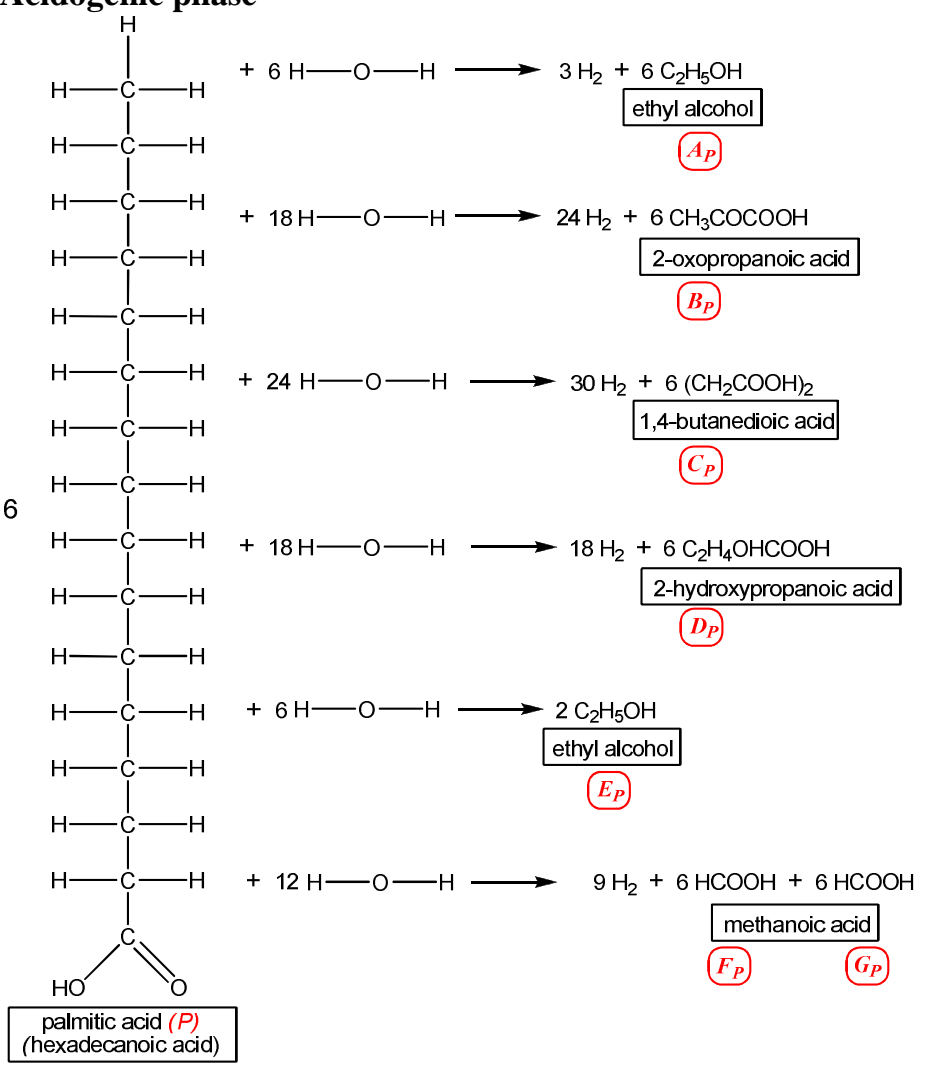

Palmitic acid triglyceride and linoleic acid triglyceride are the major components of milk fats [35]. Their hydrolysis is based on decomposition into glycerol and palmitic acid (18) and linoleic acid (19). The two acids are decomposed in the acidogenic phase into simpler chemical compounds, denoted as $A_{P}$ to $G_{P}$ for palmitic, and $A_{L}$ to $H_{L}$ for linoleic acid (20-32). The products of decomposition of the two acids comprise, essentially, the following: ethyl alcohol; 2-oxopropanoic acid; 1,4-butanedioic acid; 2-hydroxypropanoic acid; propan-2-one; methyl alcohol and methanoic acid. In considerations, it should be taken into account that glycerol - the second product of degradation of triglycerides (18 and 19) - also is biodegraded into simpler compounds. Probably, glycerol is hydrolyzed to form 
glyceric aldehyde, $\mathrm{CH}_{2}(\mathrm{OH}) \mathrm{CH}(\mathrm{OH}) \mathrm{CHO}$ and dihydroxyacetone, $\mathrm{CH}_{2}(\mathrm{OH}) \mathrm{COCH}_{2}(\mathrm{OH})$, which can also cause acidification of the mixtures digesting.

\section{Acidogenic phase}

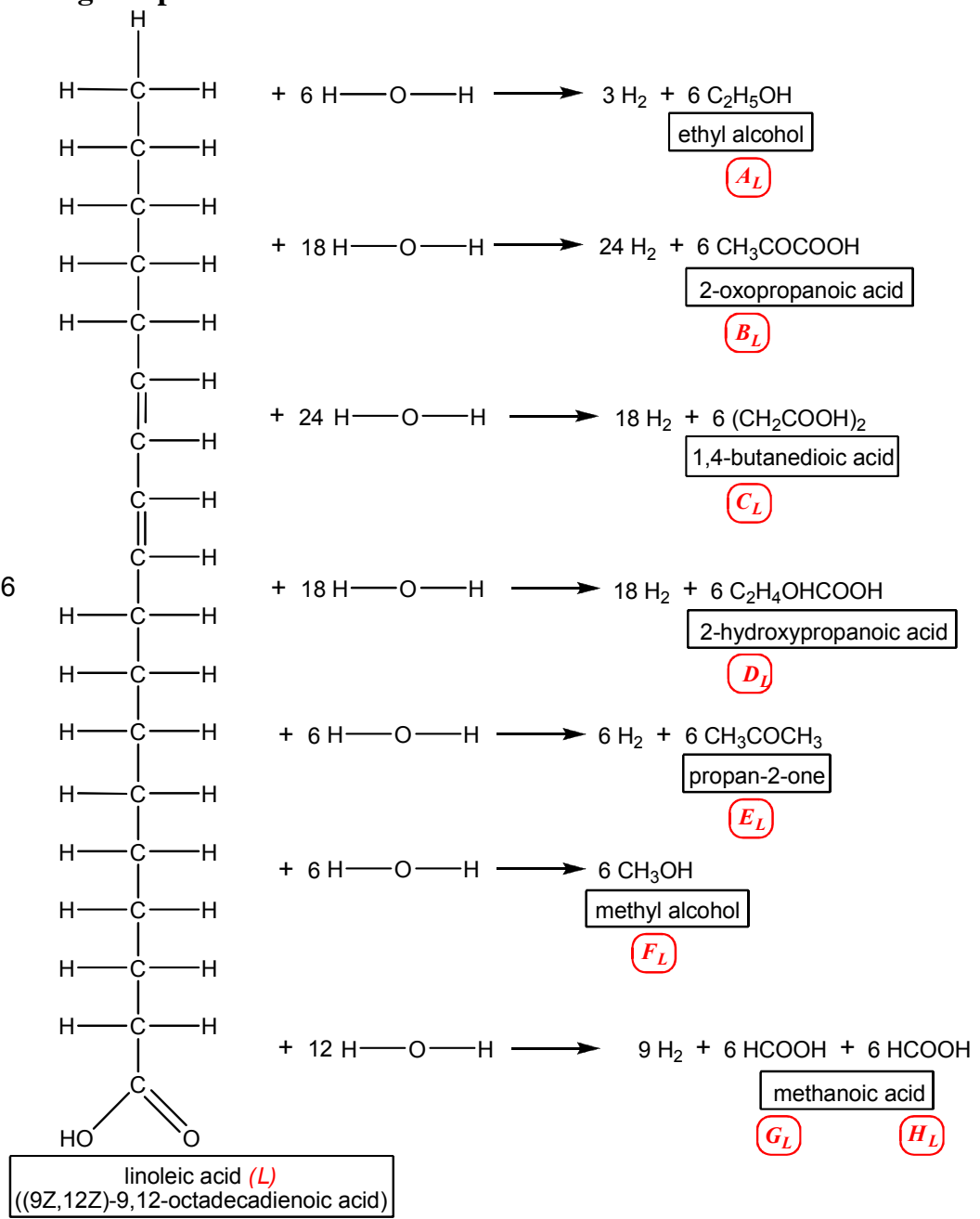

Reactions (33) to (43) take into consideration the products of decomposition of palmitic and linoleic acids. In the acetogenic phase, decomposition of ethyl alcohol (33), 2-oxopropanoic acid (34), 1,4-butanedioic acid (35), 2-hydroxypropanoic acid (37), propanoic acid (38) and propan-2-one (39) leads to ethanoic acid. Moreover, reactions (35) and (37) produce products - such as polyglycolic acid and propanoic acid - which are further decomposed, for instance into methanoic and ethanoic acid $(36,38)$. The acetogenic phase is also the source of $\mathrm{H}_{2}, \mathrm{CO}_{2}$ or even $\mathrm{CH}_{4}$ (39), which are a perfect nutrient for the methanogenic bacteria (40-43). 
Casein, is the most important protein, which representing $70 \%$ of the general volume of proteins in milk [35]. Moreover, it is qualified among phosphoproteins and glycoproteins which means that phosphate and sugar residues are incorporated in its protein chains. According to literature, casein is composed of $\mathrm{C}-53 \%, \mathrm{H}-7 \%, \mathrm{O}-22 \%, \mathrm{~N}-15.65 \%, \mathrm{~S}-$ $0.76 \%$ and $\mathrm{P}-0.85 \%$ [35].

\section{Acetogenic phase}

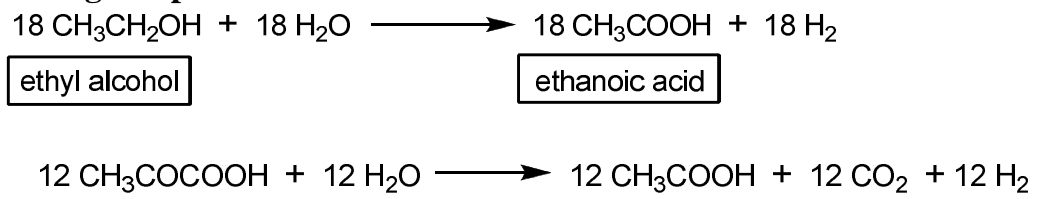

$6 \mathrm{CH}_{2}(\mathrm{OH}) \mathrm{COOH}+6 \mathrm{H}_{2} \mathrm{O} \longrightarrow 12 \mathrm{HCOOH}+6 \mathrm{H}_{2}$

\begin{tabular}{|c|c|}
\hline $\begin{array}{c}\text { polyglycolic acid } \\
\text { (2-hydroxyethanoic acid) }\end{array}$ & methanoic acid \\
\hline
\end{tabular}



\section{Methanogenic phase}

$54 \mathrm{CH}_{3} \mathrm{COOH} \longrightarrow 54 \mathrm{CH}_{4}+54 \mathrm{CO}_{2}$

ethanoic acid

$30 \mathrm{HCOOH} \longrightarrow 9 \mathrm{CH}_{4}+27 \mathrm{CO}_{2}+18 \mathrm{H}_{2} \mathrm{O}$

$6 \mathrm{CH}_{3} \mathrm{OH}+6 \mathrm{H}_{2} \longrightarrow 6 \mathrm{CH}_{4}+6 \mathrm{H}_{2} \mathrm{O}$

methyl alcohol

$198 \mathrm{H}_{2}+49.5 \mathrm{CO}_{2} \longrightarrow 49.5 \mathrm{CH}_{4}+99 \mathrm{H}_{2} \mathrm{O}$ 
General formula of casein: $\mathrm{C}_{185} \mathrm{H}_{294} \mathrm{O}_{57} \mathrm{~N}_{47} \mathrm{SP}$

Hydrolysis

n-protein-C- $\mathrm{NH}_{2}+\mathrm{H}_{2} \mathrm{O} \longrightarrow \mathrm{C}_{\mathrm{x}} \mathrm{H}_{y} \mathrm{O}_{\mathrm{z}} \mathrm{N}_{\mathrm{a}} \mathrm{S}_{\mathrm{b}}+\mathrm{c} P$

Acidogenic phase

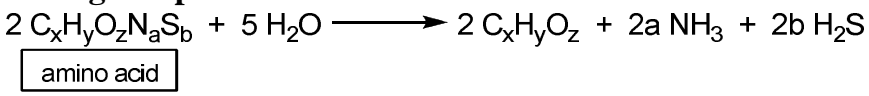

Acetogenic phase

$\mathrm{C}_{x} \mathrm{H}_{y} \mathrm{O}_{z}+\mathrm{H}_{2} \mathrm{O} \longrightarrow x \mathrm{CH}_{3} \mathrm{COOH}+\mathrm{H}_{2}$

Methanogenic phase

$x \mathrm{CH}_{3} \mathrm{COOH} \longrightarrow x / 2 \mathrm{CH}_{4}+x / 2 \mathrm{CO}_{2}$

Using the above composition, the authors of this paper found the following molecular formula of casein: $\mathrm{C}_{185} \mathrm{H}_{294} \mathrm{O}_{57} \mathrm{~N}_{47} \mathrm{SP}$. To generalize chemical reactions in the biodegradation of the rather complex compound, the authors adopted the following formula: n-protein-C- $\mathrm{NH}_{2} \mathrm{SP}$. Hydrolysis leads to decomposition of casein which is a biopolymer into amino acids $\left(\mathrm{C}_{\mathrm{x}} \mathrm{H}_{\mathrm{y}} \mathrm{O}_{\mathrm{z}} \mathrm{N}_{\mathrm{a}} \mathrm{S}_{\mathrm{b}}\right)$ and phosphate residues, $\mathrm{P}$ (44). In the acidogenic phase, decomposition of amino acids leads to the formation of simpler organic compounds, similar to those described earlier for this stage, in addition to $\mathrm{NH}_{3}$ and $\mathrm{H}_{2} \mathrm{O}$ (45). The acetogenic phase leads (46), by analogy, to the formation of acetic acid, whereas methanogenesis produces $\mathrm{CH}_{4}$ and $\mathrm{CO}_{2}(47)$.

Stability of pH. Cumulative biogas and methane yield. The BM/inoculum and $\mathrm{CW} /$ inoculum mixtures, subjected to $\mathrm{AD}$, were characterized by neutral $\mathrm{pH}$ values (Table 2 ). For the duration of the experiment (14 days), the $\mathrm{pH}$ of buttermilk was not very much affected, as shown by the profile of the $\mathrm{pH}$ curve in Figure 2. The fact results from the favorable $\mathrm{C} / \mathrm{N}$ ratio of the $\mathrm{BM} /$ inoculum mixture; the ratio was obtained by selecting suitable ratios of the mixture components. A stable course of AD for buttermilk is affected also by the chemical composition of the starting material which, according to literature data, is as follows: water $91 \%$, fat $0.50 \%$, protein $3.10 \%$, lactose $4 \%$, mineral salts $0.70 \%$, and lactic acid $0.60 \%$ [21]. Buttermilk is a readily biodegradable material which resists acidification initially in the process due to its low fat content.

Table 2

Digestion mixtures ratios and selected parameters

\begin{tabular}{|c|c|c|c|c|c|}
\hline Sample & $\begin{array}{c}\text { Substrate } \\
{[\mathbf{g}]}\end{array}$ & $\begin{array}{c}\text { Inoculum } \\
\mathbf{[ g ]}\end{array}$ & Mixtures pH & $\begin{array}{c}\text { Mixtures } \\
\text { C/N ratio }\end{array}$ & $\begin{array}{c}\text { Mixtures TS } \\
{[\%]}\end{array}$ \\
\hline BM & 100 & 900 & 7.10 & 15 & 3.87 \\
CW & 150 & 850 & 7.08 & 15 & 3.61 \\
\hline
\end{tabular}

The yield of biogas obtained in the experiment from buttermilk is rather low at $51.20 \mathrm{~m}^{3} / \mathrm{Mg}$ FM (FM - fresh matter) (Table 3). However, methane concentration in the biogas obtained from the material is high at $70.37 \%$, showing that buttermilk is a good substrate for AcoD. In terms of dry organic matter, the yield of biogas is $743 \mathrm{~m}^{3} / \mathrm{Mg} \mathrm{VS}$. 
The curves showing the daily production rates of biogas and methane (Figs. 3 and 4) have regular profiles, as the biogas output is on the increase until Day 14 (Fig. 3b).

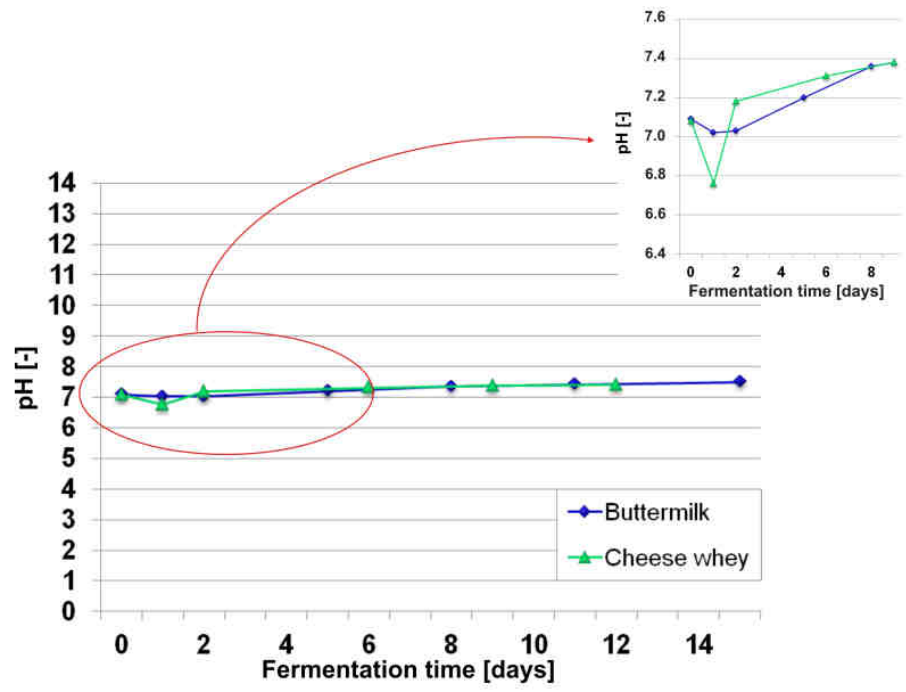

Fig. 2. pH variation profiles for buttermilk and cheese whey

Table 3

Cumulative methane and biogas yield from $\mathrm{Mg}$ of fresh matter and dry organic matter, for: $\mathrm{BM}, \mathrm{CW}$ and control

\begin{tabular}{|c|c|c|}
\hline \multirow{2}{*}{ Sample } & \multicolumn{2}{|c|}{ Fresh matter } \\
\cline { 2 - 3 } & $\begin{array}{c}\text { Cumulative methane yield } \\
{\left[\mathrm{m}^{3} / \mathrm{Mg} \mathrm{FM}\right]}\end{array}$ & $\begin{array}{c}\text { Cumulative biogas yield } \\
{\left[\mathrm{m}^{3} / \mathrm{Mg} \text { FM }\right]}\end{array}$ \\
\hline Control & 1.4 & 3.55 \\
\hline BM & 36.0 & 51.2 \\
\hline CW & 12.6 & 22.4 \\
\hline Sample & \multicolumn{2}{|c|}{ Dry organic matter } \\
\hline Control & $\begin{array}{c}\text { Cumulative methane yield } \\
{\left[\mathrm{m}^{3} / \mathrm{Mg} \text { VS }\right]}\end{array}$ & $\begin{array}{c}\text { Cumulative biogas yield } \\
{\left[\mathrm{m}^{3} / \mathrm{Mg} \text { VS }\right]}\end{array}$ \\
\hline BM & 54.7 & 144.0 \\
\hline CW & 527.0 & 743.0 \\
\hline
\end{tabular}

By contrast with buttermilk, the AD process based on cheese whey was disturbed as early as Day 1 of the experiment. The $\mathrm{pH}$ dropped to 6.75 (Fig. 2), exceeding the optimum $\mathrm{pH}$ limit for the functioning of the methanogens.

Methods proposed to offset the undesirably low $\mathrm{pH}$ include co-digestion with other materials more often than not. Moreover, chemical compounds such as bicarbonates or $\mathrm{NaOH}$ [36] have also been used for years to stabilize the $\mathrm{pH}$. The use of $\mathrm{Ca}(\mathrm{OH})_{2}$ is not recommended as it may lead to calcium sediments in the biomass [37]. Researchers found a solution to the problem of high concentration of $\mathrm{Na}^{+}$in cheese whey by adding suitable surfactants; thus, they obtained a considerable increase in the volume of biogas, including the methane share [15]. 

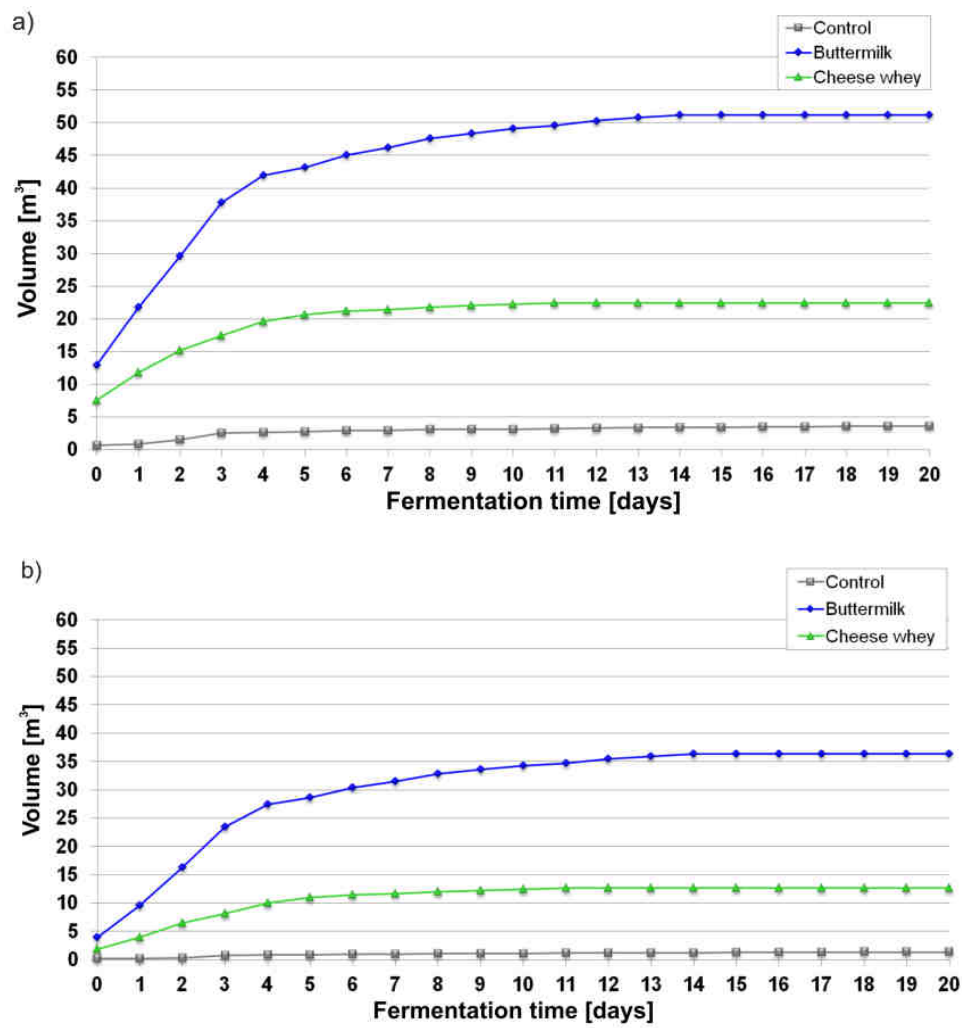

Fig. 3. Daily production of: a) biogas and b) methane from fresh matter of BM, CW and control

Reducing the $\mathrm{pH}$ on Day 1 of anaerobic digestion of cheese whey in this experiment did not essentially affect the course of the entire process of which the duration, for that particular material, was 12 days (Fig. 2). Biogas production rate was on a stable increase, as shown by the diagrams in Figures 3 and 4. However, the yield of biogas, was much lower in this case, as compared with buttermilk: the volume obtained was $22.4 \mathrm{~m}^{3} / \mathrm{Mg}$ of fresh matter (FM). This was partly due to the low value of total solids (4.43\%) for CW, as compared with BM (Table 1). The methane content of biogas is also lower for cheese whey $(56.27 \%)$ in comparison with buttermilk. The essential cause of the low methane production was the lower amount of $\mathrm{H}_{2}$. The volume of $\mathrm{H}_{2}$, generated during the degradation of $\mathrm{CW}$, results from the lower contents of fat and protein in the material: their combined concentration is $3.6 \%$ for buttermilk and ca. $1.5 \%$ for cheese whey (protein - up to $1 \%$, fat - up to $0.5 \%$ ) [12]. However, the volume of methane obtained in the tests with the use of $\mathrm{CW}$ is several percent higher compared with literature data $[17,20]$. This quite good result is connected with the stable course of AD for cheese whey. In this study, the authors used a suitable amount of digested sewage sludge as inoculum which, just as cattle slurry, enables digestion of cheese whey without addition of any chemical stabilizers or complex technological solutions [20]. 

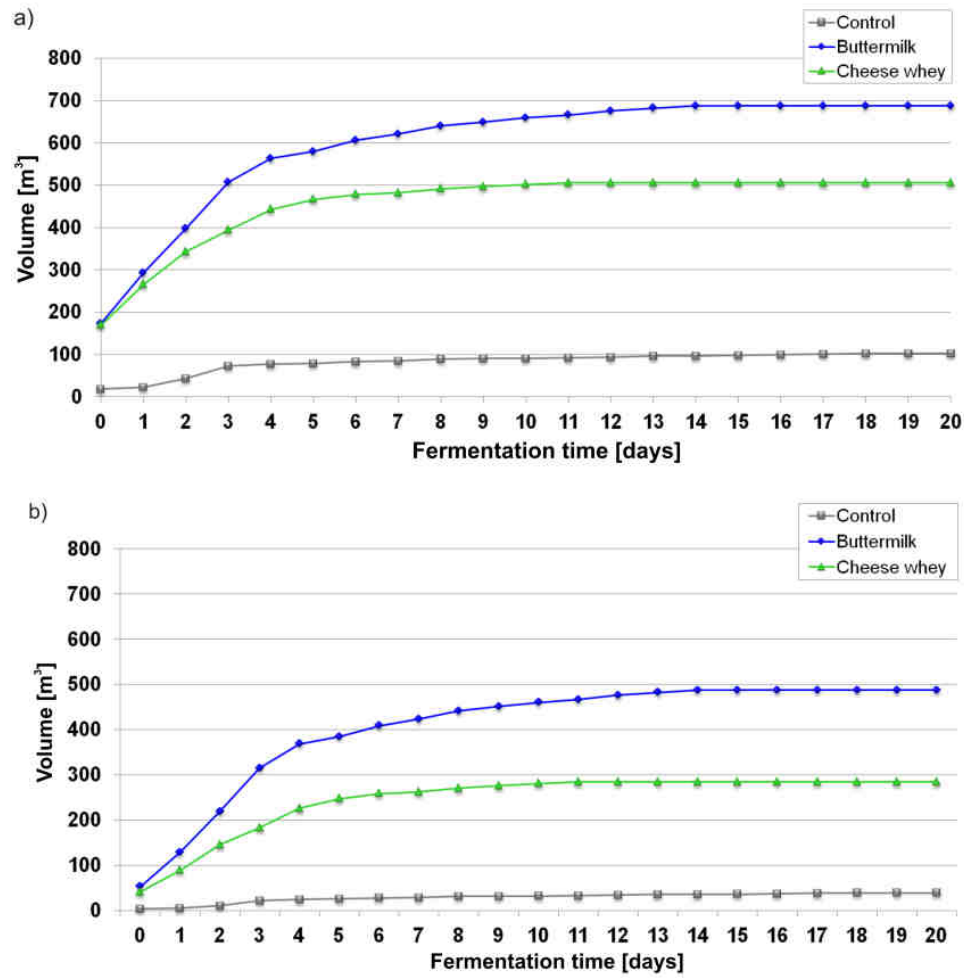

Fig. 4. Daily production of: a) biogas and b) methane from volatile solids of BM, CW and control

\section{Conclusions}

Both buttermilk and cheese whey are the types of starting materials which, having a high content of organic compounds, are useful as a feed in biogas plants. On the other hand, with their $\mathrm{pH}$ in the acidic range, low content of total solids, and low $\mathrm{C} / \mathrm{N}$ ratio, the two materials require a suitable amount of co-substrates. The digested sewage sludge which was used as the inoculum in this work, having a high buffer capacity, stabilizes perfectly the course of $\mathrm{AD}$ of dairy waste. The results obtained in this study have shown that buttermilk as a starting material for $\mathrm{AD}$ is a source of more biogas $\left(743 \mathrm{~m}^{3} / \mathrm{Mg} \mathrm{VS}\right)$, including methane $\left(527 \mathrm{~m}^{3} / \mathrm{Mg} \mathrm{VS}\right)$, as compared with cheese whey $\left(600 \mathrm{~m}^{3} / \mathrm{Mg} \mathrm{VS}\right.$, $338 \mathrm{~m}^{3} / \mathrm{Mg} \mathrm{VS}$ - biogas and methane, respectively). It was found that the reason why less biogas and less methane is obtained from cheese whey is, essentially, its lower total solids value and low content of fat and protein (a total of $1.5 \%$ or less) - a source of $\mathrm{H}_{2}$ which, in reactions with $\mathrm{CO}_{2}$, is indispensable to generate $\mathrm{CH}_{4}$. Essentially, buttermilk and cheese whey are low-efficiency substrates in $\mathrm{AD}$ and the results obtained by the authors are comparable with literature data. The authors are planning to continue a study with the use of another high-energy co-substrate, such as fats. 


\section{Acknowledgements}

The research work titled "A study of biogas production from sewage sludge with addition of external carbon sources", Project No. 6/2013, was commissioned by Aquanet S.A. water and sewage company.

The project was carried out using a research station, funded by a grant NCN no. N N313 432539: "Assessment of the fertilizer value and impact on the soil of after digest pulpy originating from the process of biogas production, with application of different organic substrates".

\section{References}

[1] Duan N, Dong B, Wu B, Dai X. Biores Technol. 2012;104:150-156. DOI: 10.1016/j.biortech.2011.10.090.

[2] Martín MA, González I, Serrano A, Siles JA. J Environ Manage. 2015;147:330-337. DOI: 10.1016/j.jenvman.2014.09.022.

[3] Mudhoo A, Kumar S. Int J Environ Sci Technol. 2013;10:1383-1398. DOI: 10.1007/s13762-012-0167-y.

[4] Dai X, Duan N, Dong B, Dai L. Waste Manage. 2013;33:308-316. DOI: 10.1016/j.wasman.2012.10.018.

[5] Borowski S, Domański J, Weatherly L. Waste Manage. 2014;34:513-521. DOI: 10.1016/j.wasman.2013.10.022.

[6] Vilniškis R, Baltrènas P, Vasarevičius S, Baltrenaite E. Ecol Chem Eng S. 2011;18(4):409-427. http://tchie.uni.opole.pl/ece_s/S18_4/S4_2011.pdf.

[7] Liu X, Wang W, Shi Y, Zheng L, Gao X, Qiao W, et al. Waste Manage. 2012;32:2056-2060. DOI: 10.1016/j.wasman.2012.03.003.

[8] Appels L, Lauwers, J, Degrève J, Helsen, L, Lievens B, Willems K, et al. Renew Sustain En Rev. 2011;15:4295-301. DOI: 10.1186/2192-0567-3-15.

[9] Athanasoulias E, Melidis P, Aivazidis A. Renew En. 2014;62:73-78. DOI: 10.1016/j.renene.2013.06.040.

[10] Chen Y, Cheng JJ, Creamer KS. Biores Technol. 2008;99:4044-4064. DOI: 10.1016/j.biortech.2007.01.057.

[11] Wan C, Zhou Q, Fu G, Li Y. Waste Manage. 2011;31:1752-1758. DOI: 10.1016/j.wasman.2011.03.025.

[12] Prazeres AR, Carvalho F, Rivas J. J Environ Manage. 2012;110:48-68. DOI: 10.1016/j.jenvman.2012.05.018.

[13] Ghaly AE. Biores Technol. 1996;58:61-72. DOI: 10.1007/BF02921537.

[14] Kavacik B, Topaloglu B. Biomass Bioenergy. 2010;34:1321-1329. DOI: 10.1016/j.biombioe.2010.04.006.

[15] Hassan AN, Nelson BK. J Dairy Sci. 2012;95:6188-6203. DOI: 10.3168/jds.2012-5732.

[16] Dareioti MA, Kornaros M. Biores Technol. 2015;175:553-562. DOI: 10.1016/j.biortech.2014.10.102.

[17] Rico C, Muńoz N, Fernández J, Rico JL. Chem Eng J. 2015;262:794-802. DOI: 10.1016/j.cej.2014.10.050.

[18] Gomez-Romero J, Gonzalez-Garcia A, Chairez I, Torres L, García-Peña EI. Int J Hydrogen Energ. 2014;39:2541-2550. DOI: 10.1016/j.ijhydene.2014.06.050.

[19] Hagen LH, Vivekanand V, Linjordet R, Pope PB, Eijsink VGH, Horn SJ. Biores Technol. 2014;171:350-359. DOI: 10.1016/j.biortech.2014.08.095.

[20] Comino E, Riggio VA, Rosso M. Biores Technol. 2012;114:46-53. DOI: 10.1016/j.biortech.2012.02.090.

[21] Sodini I, Morin P, Olabi A, Jiménez-Flores R. J Dairy Sci. 2006;89:525-536. DOI: 10.3168/jds.S0022-0302(06)72115-4.

[22] Traversi D, Bonetta S, Degan R, Villa S, Porfido A, Bellero M, et al. Bioenerg Res. 2013;6:815-863. DOI: $10.1007 / \mathrm{s} 12155-013-9341-4$.

[23] Norm VDI 4630. Vergärung organischer Stoffe Substratcharakterisierung, Probenahme, Stoffdatenerhebung, Gärversuche (in German). Fermentation of organic materials characterization of the substrate, sampling, collection of material data, fermentation tests (in English). Düsseldorf: Verein Deutscher Ingenieure German Engineers Club; 2006. http://www.vdi.eu/guidelines/vdi_4630vergaerung_organischer_stoffe_substratcharakterisierung_probenahme_stoffdatenerhebung_gaerversuche/.

[24] Norm DIN 38 414-S8. Bestimmung des Faulverhaltens (S8) Schlamm und Sedimente (in German). Fermentation of organic materials - Characterisation of the substrate, sampling, collection of material data, fermentation tests. Berlin: Deutsches Institut für Normung; 1985. https://www.beuth.de/de/norm/din-384148/1209064.

[25] Pilarska A, Pilarski K, Krysztofiak A, Dach J, Witaszek K. Agric Eng. 2014;3:139-148. DOI: http://dx.medra.org/10.14654/ir.2014.151.066. 
[26] Norm PN-EN ISO 5667-13:2011. Jakość wody - Pobieranie próbek - Część 13: Wytyczne dotyczące pobierania próbek osadów (Water quality - Sampling - Part 13: Guidance on sampling of sludges). Warszawa: Polish Comittee for Standarization; 2011. http://sklep.pkn.pl/pn-en-iso-5667-13-2011e.html.

[27] Norm PN-EN ISO/IEC 17025:2005. Ogólne wymagania dotyczące kompetencji laboratoriów badawczych i wzorcujących (General requirements for the competence of testing and calibration laboratories). Warszawa: Polish Comittee for Standarization; 2005. http://sklep.pkn.pl/pn-en-iso-iec-17025-2005p.html.

[28] Norm PN-EN ISO 9963-1:2001. Jakość wody - Oznaczanie zasadowości - Część 1: Oznaczanie zasadowości ogólnej i zasadowości wobec fenoloftaleiny (Water quality - Determination of alkalinity - Part 1: Determination of total alkalinity and alkalinity in the presence of phenolphthalein). Warszawa: Polish Comittee for Standarization; 2001. http://sklep.pkn.pl/pn-en-iso-9963-1-2001p.html.

[29] Poggi-Varaldo HM, Rodríguez-Vázquez R, Fernández-Villagómez G, Esparza-Garciá F. Appl Microbiol Biotechnol. 1997;47:284-291.

[30] Deublein D, Steinhauser A. Biogas from waste and renewable resources. $2^{\text {nd }}$ Ed. Weinheim: Wiley-VCH Verlag GmbH \& Co.KGaA; 2011. DOI: 10.1002/9783527632794.ch8.

[31] Waszkielis KM, Wronowski R, Chlebus W, Bialobrzewski I, Dach J, Pilarski K, et al. Ecol Eng. 2013;61:354-357. DOI: 10.1016/j.ecoleng.2013.09.024.

[32] Pilarska A, Lukosek M, Siwińska-Stefańska K, Pilarski K, Jesionowski T. Pol J Chem Technol. 2014;16(2):36-42. DOI: 10.2478/pjct-2014-0027.

[33] Pilarska A, Nowacka M, Pilarski K, Paukszta D, Klapiszewski L, Jesionowski T. Physicochem Probl Miner Process. 2013;49:701-702. DOI: 10.5277/ppmp130228.

[34] Berg JM. Biochemistry. Sixth Ed. New York: WH. Freeman; 2007. https://openlibrary.org/books/OL3428294M/Biochemistry.

[35] Berlitz HD, Grosch W. Food Chemistry. 4th revised and extended edition. Berlin Heidelberg: Springer-Verlag; 2009. DOI: 10.1007/978-3-540-69934-7.

[36] Yang K, Yu Y, Hwang S. Water Res. 2003;37:2467-2477. DOI: 10.1016/S0043-1354(03)00006-X.

[37] El-Mamouni R, Guiot SR, Mercier P, Safi B, Samson R. Bioprocess Eng. 1995;12:47-53. DOI: 10.1007/BF01112993. 